\title{
Life Narratives of the Lankan Other: An Exploratory Study of the Jaffna Community in "Project I Am"
}

\author{
Lakshani Willarachchi \\ General Sir John Kotelawala Defence University, Ratmalana, Sri Lanka
}

\begin{abstract}
Life narrative is a field which is currently drawing increasing academic interest in Sri Lanka, though life narratives are an integral part of the socio-political fabric of the nation. In the Sri Lankan, context biography and autobiography are commonly seen as two separate genres in life writing, but certain life narratives tend to blur those boundaries. From This Point Forward, a photography exhibition by Luka Alagiyawanna, My Mother's Village, a documentary life narrative by Aaron Burton, and Project I Am by Kannan Arunasalam are some examples. The present study analyses life narratives from I Am Jaffna section in Project I $\mathrm{Am}^{1}$; a digital archive of life narratives of Sri Lankan elders. Based on the life narratives, memories, and experiences of Sri Lankan elders, the project strives to find out whether there was a time when people in Sri Lanka did not describe themselves as Sinhalese, Tamil, Muslim, or Burgher, or a time when ethnic identity was not the primary defining factor of an individual. The reviews and articles on the projects have looked at the project merely as a repository of stories that help Sri Lankans understand their differences and a project promoting reconciliation with hardly any focus on the project as a Sri Lankan life narrative, so that a gap bridged by the present study. The study also focuses on the concept and politics of "othering" with a view to exploring how these life narratives are constructed as Sri Lankan life narratives. For this purpose, the study focuses on the segment on people from Jaffna-I am Jaffa, since the Jaffna community has a long standing history of being "the other." The inseparability of the concept and politics of othering and the identity of Sri Lankans show that it is extremely challenging to dispose of the notion of the other as it has actually become an integral aspect of Sri Lankan identity and a social reality.
\end{abstract}

Keywords: life writing, Project I Am, Sri Lankan life narratives

\section{Setting the Camera}

Life narrative is a comparatively novel field of interest in Sri Lanka, though life narratives are always woven into the socio-political fabric of the nation. Despite having numerous biographies and autobiographies written on Sri Lankans, there still is a lack of academic studies conducted on them particularly in a life narrative angle. In the Sri Lankan, context too biography and autobiography have traditionally been categorized as two separate genres in life writing, but certain life narratives tend to blur those boundaries. From This Point Forward, a photography exhibition by Luka Alagiyawanna, My Mother's Village, a documentary life narrative by Aaron Burton, and Project I Am by Kannan Arunasalam are examples of works based on Sri Lankan lives which blur the boundary between autobiography and biography.

\footnotetext{
Lakshani Willarachchi, Lecture, Department of Languages, General Sir John Kotelawala Defence University.

${ }^{1}$ see http://www.iam.lk.
} 
The focus of the present study, Life Narratives of the Lankan Other: An Exploratory Study of the Jaffna Community in 'Project I Am' Project I Am (see http://www.iam.lk) creates a digital archive of life narratives of Sri Lankan elders where the fluidity of the narratives and the genres are reflected through the blurring of the boundary between autobiography and biography. According to Smith and Watson (2001, p. 183), recent independent filmmaking in European countries has brought diverse kinds of personal stories and innovative modes of self-representation to the fore and this influence is evident in Arunasalam's production. Based on the life narratives, memories and experiences of Sri Lankan elders, the project strives to answer the question "Was there a time when people in Sri Lanka did not describe themselves as Sinhalese, Tamil, Muslim, or Burgher? Or at least when these identities were not foremost in their minds?" (Arunasalam, 2009). The reviews and articles on the projects have looked at the project merely as a project that aims to capture disappearing narratives of Sri Lanka to understand our divisions better (Bandara, 2013) and a project promoting reconciliation with hardly any focus on the project as a Sri Lankan life narrative. The present study attempts to bridge a gap and the study would also focus on the concept and politics of othering with a view to exploring how these life narratives are constructed as Sri Lankan life narratives. For this purpose, the study focuses on the segment on people from Jaffna-I am Jaffna, since the Jaffna community has a long standing history of being "the other" and the primary method of analysis is content with analysis of the primary data (i.e. the videos from the project) and secondly readings.

\section{Capturing and Production of the Others' Image and Narratives}

It is understood that "life narrative ..." is a general term for acts of self-representation of all kinds and in diverse media that take the producer's life as their subject, whether written, performative, visual, filmic, or digital" (Smith \& Watson, 2001, p. 4).

Bearing this in mind, it can be argued that on the one hand the project is the life narrative of many Sri Lankan elders constructed by Kannan Arunasalam, since it is his captures, recordings, editing, and production. On the other hand, however, it has an undeniable autobiographical element since the life stories, memories, and experiences are narrated by the subjects themselves. Kenneth Plummer says, "We are constantly writing the story of the world around us: its periods and places, its purposes and programmes, and its people and plots. We invent identities for ourselves and others and locate ourselves in these imagined maps" (Plummer, 1995, p. 20).

The same phenomenon is at work in Project I Am, where the life narrators are engaged in a process of narrating segments from the history of Sri Lanka, along with their personal histories, in which the identity and the self of the subjects and the producer himself are located. As Arunasalam (2009) states the project has also been a mode of exploring his own links with the country, ethnic identity, and selfhood. The introductory notes and comments of the producer provides insights as to how he resolves certain questions, doubts, and conflicts in himself as a diasporic filmmaker born British who is both an insider as well as an outsider simultaneously. In fact, many of the life narratives compiled address the issues of insider/outsider, centre/periphery vis-à-vis the concept and politics of the other. Thus, the present study intends to explore the construction of these narratives as Sri Lankan life narratives with special focus on the concept of the other found in the narratives.

The producer employs multiple modes of production, such as photographs, voice recordings/voiceovers, background noise, and his own commentary and notes in imbuing a sense of Sri Lankan authenticity in the life narratives each consisting of a montage and voice recordings. Mrs. Subramanium (the independent), for instance, is shown as an independent career woman who is very much part of the life in Jaffna. Often, her 
narrative segments' break is indicated by the ringing of a telephone at the newspaper office and she answering it. This can be seen as an attempt of the producer to bring in an element of realism and authenticity to the life which is being narrated.

At other times, however, the readers feel the presence of a coaxer who interviews the subjects and frames their narrative through his questions and prompts. These folk (e.g., coaxers, coachers, and coercers) possess the power, at least momentarily to provoke stories from people (Plummer, 1995, p. 21). So, the perverse spectatorship (Oishi, 2006) of the post-modern context perceives the contractedness of the narrative. This is juxtaposed with the attempts of imbuing realism into the narrative and it makes the boundary between the real and constructed fissured. The viewers too can bring in their own understandings into the process of meaning making in this manner and the online environment, in which the project is set, facilitates the viewers in leaving comments as a mode of active engagement with the life narratives. The viewers would comment if the narrators are known to him/her, often adding more information/insights to the lives narrated. By making room for the viewers to contribute to the construction of the life narrative, the notion of biography is made further complex.

The photographs, especially the montage, accompanying each narrative enable them to cross boundaries of genres. The objects/belongings of the subjects that are photographed, for instance, brings in auto-topography (Smith \& Watson, 2001) where certain memories, experiences, and biographical details are embedded in the objects.

Mrs. Subramanium (the independent), J. Jegatheeswaran (the taxi driver), Sri Naguleswara Kurukkal (the chief priest), Dr. Sivarajah (the community doctor), and Dr. Thomas Saundaranayagam (the bishop) narrate how their lives have been woven in and around times of peace and war. However, their memories are of a time where the people of Jaffna irrespective of their race, religion, class, or caste suffered and fought for survival alike.

Still, what is of greater interest is to examine the ways, in which the narratives bring forth the notion of the "other" through these individuals who are constructed as an integral part of Sri Lanka (i.e., "I am Jaffna," "I am Kandy etc." since otherness is seen as a fundamental element of defining identity in these narratives.

Tamils in Sri Lanka have long been identified as an ethnic minority and an "other," especially in the wake of Sinhala Buddhist nationalism preceding and following the independence. As Haraprasad Chattopadhyaya (1994, p. 16) pointed out,

The discriminatory government policy towards the Ceylon Tamils in matters of language, education, and employment, the very fields of advancement traditionally highly prized by them, produced an adverse reaction amongst them creating a rupture between the two ethnic groups where the Tamils felt othered in their native land.

In her narrative, Sister Pushpam Gnanapragasam (the Nun) comments that after the independence there was a "distinct awakening to differences" (Project I Am, 2010-2012) based on racial discrimination. However, though much of the popular evidence suggests this view, the nun's narrative reveals a different perspective. She says that even before independence the Jaffna people were used to thinking in terms of "our people," an instant demarcation between "them and us." She claims that it is something in-built and though they are always capable of extending fraternity towards the Sinhalese, they are essentially seen as the other. She constantly refers to Jaffna people and it is noteworthy that the opposite of Jaffna or "our people" is the Sinhalese which reveals that she identifies the Tamils as Jaffna people. So, it can be argued that the notion of the other existed prior to its aggravation by any discriminatory government policy. 
Narrating their lives and relationship with Jaffna though they live in Kandy, the life narratives of V. S Alagan and C. K Sankarakumaran (I am Kandy) depict how they never felt as the "other" or an outsider when visiting/living in Jaffna. Alagan says that he has faced no issues during his years spent in Jaffna and would not even mind settling down there and Sankarakumaran says that he always felt warmly welcomed and perfectly at home in Jaffna as well (Project I Am, 2010-2012). Does it then mean that the notion of the other exists only in relation to the Sinhala and Tamil ethnicities? The co-existence of multiple narratives further complexes this. The notion of the other seems to be an integral part of the socio-cultural fabric of Jaffna Tamil people. The narratives of Sister Pushpam Gnanapragasam (the Nun), Dominic Jeeva (the activist), and T. Arasanayagam (the other), for instance, refer to the others inside the Tamil community. Though the two life narratives of the Kandyan Tamils project Jaffna Tamil community as a welcoming, friendly community, the life narratives of Dominic Jeeva and T. Arasanayagam reveal the seamier side of their culture where fellow Jaffna Tamils are othered by means of caste politics.

The son of a Jaffna barber, Dominic Jeeva, has become a writer-activist against social discrimination based on caste. He comments, "From Jaffna Society's point of view, we are from lower caste...The so called high caste, the 'Vellalahs' never accepted us," revealing how they were marginalized within the community (Project I Am, 2010-2012). In terms of life writing, he identifies this as one of the decisive factors which created self and it was his extremism, meanness, and cruelty that created Jeeva (Project I Am, 2010-2012). From the point, he dropped out of school following the remark "Why do not you go and shave someone without troubling us?" Jeeva has been struggling against caste discrimination where the upper castes denied the lower castes the right of speech, education, ownership of land (in specific areas reserved for the upper castes), social mobility etc. In his view, it is this othering that has a more direct impact on affecting and shaping the lives of the people. We never had any hatred for the Sinhalese, but we could not bear the discrimination in the name of caste by the Tamil man (Project I Am, 2010-2012). Jeeva argues that caste based discrimination still continues though some have commented that caste system is fast effacing in the post-war context. He points out that even the diasporic Tamil communities in Canada and Australia are maintaining the caste system building separate temples for different castes, ending his narrative with the question, "If the old Jaffna caste system has really disappeared, how can it appear in Canada?" (Project I Am, 2010-2012). For Jeeva, "the Jaffna man" by and large is the oppressive upper caste Tamil. But he admires the strength in him, "He dug and dug at the soil, and educated his son to become a government agent ... when it comes to caste, he is weak. That is why I criticize him." (Project I Am, 2010-2012). Thus, he pinpoints a negative trait in the Sri Lankan Jaffna Tamils, though it does not deter him from projecting himself as a Jaffna man, blurring the boundary between the oppressive upper caste Tamils and the oppressed lower caste Tamils.

Recollecting his first and subsequent encounters with the concept and politics of the other, $\mathrm{T}$. Arasanayagam says (Project I Am, 2010-2012),

This other has come to me at that time. But having come to the South and lived here, they made us the other, and now I say I am the other. I have made you the other, and I have become the other here, because the Sinhalese made us the other. I do not know why they made us the other.

The politics of inclusion and exclusion play two different games here: one between ethnic groups and one within the ethnic groups. It is implied that David, his childhood friend, belonged to a community of fisher folks of a lower caste, hence his mother's indignation over him visiting "that side." He contrasts this memory with 
his later experiences as the marginalized other once he started living in the South. His narrative also brings into light the "duplicity" instilled in the high caste Tamils when he narrates an experience where he mistreated a low caste young man who visited his house by not offering him a chair. The stinging remarks of the young man who said he was a Christian now and had no caste and the subsequent criticism of his wife made him realize how the traditional notions of class and caste were in conflict with his liberal attitudes making him become a hypocrite at times. The narrative here shows how the caste system victimizes the upper caste as well as the lower caste. Fearing the punitive element in treating the lower castes as equals, even educated and supposedly liberal individuals like Arasanayagam do not defy the caste system and its politics when they are in Jaffna. For him, the geographical distancing from Jaffna enables him to move beyond caste limitations, but he is bound by those restrictions when he is in Jaffna.

This shows how Arasanayagam's and Jeeva's narratives as insiders of the Jaffna Tamil community complement each other in revealing the operations of caste politics, which could be not seen or ignored by Tamils in Kandy or people belonging to other communities. The issue of "the other" here is depicted as a "truth" known and experienced by Jaffna Tamils. This "truth" differs from the "truth" seen by the outsiders. The narratives operate collaboratively constructing the lives of Jaffna Tamils, often uniting them in this witnessing of the politics of the other in Jaffna Tamil community.

Some narratives, including that of Arasanayagam, relate the witnessing and trauma of communal violence springing from ethnic tensions as they were labeled as the ethnic other or the Tamil other. Recollecting his experiences of ethnic conflicts from 1958, Arasanayagam claims that he learnt the essential art of survival through shrewd thinking propelled by sheer terror. This has re-shaped his life in its interesting embodiment of both the oppressor and the oppressed or the centre and the margin in the same individual. Smith and Watson (2005, p. 367) posited "the body as a site of knowledge and knowledge production" in life narratives. The lived experiences of Arasanayagam and the realities he embodies in terms of his fluid identity as the norm and the other present the viewers certain information and knowledge about the undercurrent of "otherness" which has become a governing factor of life in Sri Lanka. Thus, this kind of embodiment enables varied discourses on the other.

The politics of the centre, periphery and the marginalized other do not rest there. The life narrative of Mohammed Yassasin (the dove keeper) reveals how their lives were turned upside down as they were displaced suddenly when the then LTTE political leader Nilambaram announced the eviction of Muslims from the Jaffna peninsula within two hours. Pathmanadan (the teacher) admits the fact that the Tamils of Jaffna have been silent witnesses to the very unjust eviction of the Muslims (Project I Am, 2010-2012). In his introduction to Pathmanadan, Arunasalam writes "I have covered the story of the expulsion of Muslims from Jaffna before, but Mr. Pathmanadan is the only Tamil I have met who actually admitted to the guilt that he still feels" (Arunasalam, 2010-2012). According to Smith and Watson (2005, p. 356), "At times, the act of witnessing may open traumatic wounds for the narrator rather than offer healing and reconciliation," and this is reflected in Pathmanadan's narrative. In his life narrative, this comes as a form of confessional narrative where he expresses his guilt and sadness about being unable to help his Muslim friends. He asks, "How can I face my Muslim friends?" (Project I Am, 2010-2012), revealing the deep sense of helplessness, shame, and guilt though he was not personally responsible for the eviction of another minority community. It is said that "of all the genres of photography, the most charismatic, and therefore, the most difficult to resolve successfully, is the portrait. A portrait photograph immediately grabs the viewer's attention and triggers profoundly personal 
responses-emotional, paradoxical, and not always rational" (Badger, 2007, quoted in Roberts, 2011). The portrait of the speaker here is powerful in conveying all these nuances. The projection of this guilt is also part of the production process of the narrative. In other words, it is Arunasalam who first gets the notion that there is guilt in his subject. Therefore, he captures a guilt-stricken image of the narrator and when coupled with the voice over which bear traces of pain, shame, and desperation the viewer is made to receive the image and the story intended to be delivered by the producer. This supports the view that what the viewers behold is a final product subjected to much selection and editing before they see it.

The concept and the politics of the other in Jaffna seem to be a chain where one othered group marginalizes another group and make them the other. So, the life narratives of the subjects here often contain multiple layers of oppression that govern and condition their lives and life stories.

It is also noteworthy that there is a lapse in terms of representation in the section I am Jaffna where there is an absence of women's life narratives and stories save the two narratives of Sister Pushpam Gnanapragasam and Mrs. Subramanium. Though there are multiple narratives and views on the concept and politics of othering from the men folk, the section does not include the women's views on the issue from varied angles which become a limitation for the present study.

\section{Conclusion: Framing the Other}

Focusing on Sri Lankan elders as repositories of history, traditions, and knowledge, Project I Am presents their life narratives as inseparable from the socio-political fabric of the country. The techniques, modes, and tropes of life narration employed by the producer are not limited to Sri Lankan life narratives, but the images, people, and stories captured and presented abound with a distinct Sri Lankan flavor and ambience. The study explored the concept and politics of othering and the other as a special trope in Sri Lankan life narratives. The analysis of the life narratives made it evident that though Kannan Arunasalam proposes reconciliation through his life narratives, the inseparability of the concept and politics of othering, and the identity of Sri Lankans show that it is extremely challenging to dispose of the notion of the other as it has become an integral aspect of Sri Lankan identity and a social reality. The narrators in Project I Am are commenting on this issue in post-conflict times and narratives, such as Dominic Jeeva's indicate that though othering may have been reduced in times of war, the caste issues are rearing its ugly head in post-conflict Sri Lanka as well as in other countries where Lankan Tamils have settled. These narratives thus have the potential of making us aware of such pressing concerns in a country that promotes reconciliation, as they broaden people's understandings of reconciliation by making them realize that reconciliation includes eradicating inter-racial as well as intra-racial forms of othering. Hence, it can be concluded that viewing and analyzing life narratives of Sri Lankan elders are significant in promoting reconciliation.

\section{References}

Bandara, S. (2013). I Am: A project that aims to capture Disappearing Narratives of Sri Lanka. Retrieved from http://www.colombotelegraph.com

Bhabha, H. (1996). The other question. In P. Mongia (Ed.), Contemporary postcolonial theory: A reader (pp. 37-53). Oxford: Oxford University Press.

Chattopadhyaya, H. (1994). Ethnic unrest in Modern Sri Lanka: An account of Tamil-Sinhalese race relations. Colombo: MD Publications Pvt. Ltd.

Oishi, E. (2006). Visual perversions: Race, sex, and cinematic pleasure. New Feminist Theories of Visual Culture, 31(3), 641-674. Plummer, K. (1995). Telling sexual stories: Power, change and social worlds. London: Routlegde. 
Roberts, B. (2011). Photographic portraits: Narrative and memory. Retrieved from http://www.qualitative-research.net Smith, S., \& Watson, J. (2001). Sixty genres of life narrative. A guide for interpreting life narratives. Minneapolis: University of Minnesota Press.

Smith, S., \& Watson, J. (2005). The trouble with autobiography: Cautionary notes for narrative theorists. In J. Phelan \& P. J. Rabinowitz (Eds.), A companion to narrative theory. Australia: Blackwell Publishing Ltd. 